\title{
Erratum to: Relationship Between Vitamin D Deficiency and the Components of Metabolic Syndrome in Patients with Morbid Obesity, Before and 1 Year After Laparoscopic Roux-en-Y Gastric Bypass or Sleeve Gastrectomy
}

\author{
Ana Obispo Entrenas ${ }^{1}$ - David Legupin Tubio ${ }^{2}$ - Fabiola Lucena Navarro ${ }^{1}$. \\ Francisco Martín Carvajal ${ }^{1} \cdot$ Norberto Gandara Adan $^{1} \cdot$ Maximino Redondo Bautista $^{3}$. \\ Jimena Abiles Osinaga ${ }^{4}$
}

Published online: 29 December 2016

(C) Springer Science+Business Media New York 2016

\section{Erratum to: OBESITY SURGERY DOI 10.1007/s11695-016-2445-0}

A number of errors in referencing were present in the original article. Below are the correct references and their locations in the article.

On the third page of the article, right-hand column, thirteen lines from the top of the page the correct references should be $[14,32,30]$.

On the fourth page of the article, left-hand column, six lines from the top of the page the correct references should be [51-54].

On the fourth page of the article, left-hand column, eight lines from the top of the page the correct reference should be [55]. On the fourth page of the article, left-hand column, thirteen lines from the top of the page the correct references should be $[56,57]$.

The online version of the original article can be found at http://dx.doi. org/10.1007/s11695-016-2445-0

Ana Obispo Entrenas anabichop@hotmail.com

1 Department of Bariatric Surgery, Costa del Sol Hospital, Marbella, Málaga, Spain

2 Department of Gastroenterology Surgery, Costa del Sol Hospital, Marbella, Málaga, Spain

3 Department of Surgical Specialties, Biochemical and Immunological, Faculty of Medicine, Malaga University, Malaga, Spain

4 Department of Clinical Nutrition, Costa del Sol Hospital, Marbella, Málaga, Spain
On the fourth page of the article, left-hand column, twentyseven lines from the top of the page the correct reference should be [58].

On the fourth page of the article, left-hand column, thirty-two lines from the top of the page the correct reference should be [59].

On the fourth page of the article, left-hand column, thirty-three lines from the top of the page the correct reference should be [60].

1. Ricci C, Gaeta M, Rausa E, Asti E, Bandera F, Bonavina L. Long-term effects of bariatric surgery on type II diabetes, hypertension and hyperlipidemia: a meta-analysis and metaregression study with 5-year follow-up. Obes Surg. 2015 Mar;25(3):397-405.

2. Zhang Y, Wang J, Ju W, Sun X, Cao Z, Cao Z, et al. Laparoscopic sleeve gastrectomy versus laparoscopic Rouxen-Y gastric bypass for morbid obesity and related comorbidities: a meta-analysis of 21 studies. Obes Surg. 2015 Jan.;25(1):19-26.

3. Martini F, Anty R, Schneck A-S, Casanova V, Iannelli A, Gugenheim J. Predictors of metabolic syndrome persistence 1 year after laparoscopic Roux-en-Y gastric bypass. Surg Obes Relat Dis Off J Am Soc Bariatr Surg. 2015 Feb. 25;

4. Nora M, Guimarães M, Almeida R, Martins P, Gonçalves G, Santos M, et al. Excess body mass index loss predicts metabolic syndrome remission after gastric bypass. Diabetol Metab Syndr. 2014;6(1):1.

5. Wang C. Role of vitamin $d$ in cardiometabolic diseases. J Diabetes Res. 2013;2013:243,934.

6. Grace C, Vincent R, Aylwin SJ. High prevalence of vitamin D insufficiency in a United Kingdom urban morbidly obese population: implications for testing and treatment. Surg Obes Relat Dis Off J Am Soc Bariatr Surg. 2014 Apr;10(2):355-60. 
7. Earthman CP, Beckman LM, Masodkar K, Sibley SD. The link between obesity and low circulating 25-hydroxyvitamin D concentrations: considerations and implications. Int J Obes 2005. 2012 Mar;36(3):387-96.

8. Barchetta I, De Bernardinis M, Capoccia D, Baroni MG, Fontana M, Fraioli A, et al. Hypovitaminosis D is independently associated with metabolic syndrome in obese patients. PloS One. 2013;8(7):e68689.

9. Kayaniyil S, Vieth R, Harris SB, Retnakaran R, Knight JA, Gerstein HC, et al. Association of 25(OH)D and PTH with metabolic syndrome and its traditional and nontraditional components. J Clin Endocrinol Metab. 2011 Jan.;96(1):168-75.

10. Artaza JN, Mehrotra R, Norris KC. Vitamin D and the cardiovascular system. Clin J Am Soc Nephrol CJASN. 2009 Sep.;4(9):1515-22.

11. Osei K. 25-OH vitamin D: is it the universal panacea for metabolic syndrome and type 2 diabetes? J Clin Endocrinol Metab. 2010 Sep.;95(9):4220-2.

12. Salehpour A, Hosseinpanah F, Shidfar F, Vafa M, Razaghi M, Dehghani S, et al. A 12-week double-blind randomized clinical trial of vitamin $\mathrm{D}_{3}$ supplementation on body fat mass in healthy overweight and obese women. Nutr J. 2012;11:78. 13. vinh quốc Lu'o'ng K, Nguyễn LTH. The beneficial role of vitamin $\mathrm{D}$ in obesity: possible genetic and cell signaling mechanisms. Nutr J. 2013;12:89.

14. Grineva EN, Karonova T, Micheeva E, Belyaeva O, Nikitina IL. Vitamin D deficiency is a risk factor for obesity and diabetes type 2 in women at late reproductive age. Aging. $2013 \mathrm{Jul} ; 5(7): 575-81$.

15. Goldner WS, Stoner JA, Thompson J, Taylor K, Larson L, Erickson J, et al. Prevalence of vitamin D insufficiency and deficiency in morbidly obese patients: a comparison with nonobese controls. Obes Surg. 2008 Feb.;18(2):145-50.

16. Ducloux R, Nobécourt E, Chevallier J-M, Ducloux H, Elian N, Altman J-J. Vitamin D deficiency before bariatric surgery: should supplement intake be routinely prescribed? Obes Surg. 2011 May;21(5):556-60.

17. Carlin AM, Rao DS, Meslemani AM, Genaw JA, Parikh NJ, Levy S, et al. Prevalence of vitamin D depletion among morbidly obese patients seeking gastric bypass surgery. Surg Obes Relat Dis Off J Am Soc Bariatr Surg. 2006 Apr;2(2):98103; discussion 104.

18. Newbury L, Dolan K, Hatzifotis M, Low N, Fielding G. Calcium and vitamin $\mathrm{D}$ depletion and elevated parathyroid hormone following biliopancreatic diversion. Obes Surg. 2003 Dec;13(6):893-5.

19. Ybarra J, Sánchez-Hernández J, Gich I, De Leiva A, Rius $\mathrm{X}$, Rodríguez-Espinosa J, et al. Unchanged hypovitaminosis $\mathrm{D}$ and secondary hyperparathyroidism in morbid obesity after bariatric surgery. Obes Surg. 2005 Mar;15(3):330-5.

20. Standards of Medical Care in Diabetes - 2009. Diabetes care. 2009 Jan.;32(Suppl 1):S13-61.
21. Brethauer SA, Kim J, El Chaar M, Papasavas P, Eisenberg $\mathrm{D}$, Rogers A, et al. Standardized outcomes reporting in metabolic and bariatric surgery. Obes Surg. 2015 Apr;25(4):587-606.

22. Desiderio J, Trastulli S, Scalercio V, Mirri E, Grandone I, Cirocchi R, et al. Effects of laparoscopic sleeve gastrectomy in patients with morbid obesity and metabolic disorders. Diabetes Technol Ther. 2013 Dec;15(12):1004-9.

23. Alberti KGMM, Eckel RH, Grundy SM, Zimmet PZ, Cleeman JI, Donato KA, et al. Harmonizing the metabolic syndrome: a joint interim statement of the International Diabetes Federation Task Force on Epidemiology and Prevention; National Heart, Lung, and Blood Institute; American Heart Association; World Heart Federation; International Atherosclerosis Society; and International Association for the Study of Obesity. Circulation. 2009 Oct 20;120(16):1640-5.

24. Ferder M, Inserra F, Manucha W, Ferder L. The world pandemic of vitamin $\mathrm{D}$ deficiency could possibly be explained by cellular inflammatory response activity induced by the renin-angiotensin system. Am J Physiol Cell Physiol. 2013 Jun 1;304(11):C1027-39.

25. Pilz S, Tomaschitz A, März W, Drechsler C, Ritz E, Zittermann A, et al. Vitamin D, cardiovascular disease and mortality. Clin Endocrinol (Oxf). 2011 Nov;75(5):575-84.

26. Weisman Y. Vitamin D deficiency and insufficiency. Isr Med Assoc J IMAJ. 2013 Jul;15(7):377-8.

27. Alshahrani F, Aljohani N. Vitamin d: deficiency, sufficiency and toxicity. Nutrients. 2013;5(9):3605-16.

28. Moore CE, Sherman V. Vitamin D supplementation efficacy: sleeve gastrectomy versus gastric bypass surgery. Obes Surg. 2014 Dec;24(12):2055-60.

29. Moizé V, Deulofeu R, Torres F, de Osaba JM, Vidal J. Nutritional intake and prevalence of nutritional deficiencies prior to surgery in a Spanish morbidly obese population. Obes Surg. 2011 Sep.;21(9):1382-8.

30. Lorenzo J, Boente R, Sas Fojón M. [Vitamin D deficiency and obesity]. Endocrinol Nutr Órgano Soc Esp Endocrinol Nutr. 2012 Jul;59(6):401-2.

31. Al-Daghri NM, Alkharfy KM, Al-Othman A, El-Kholie E, Moharram O, Alokail MS, et al. Vitamin D supplementation as an adjuvant therapy for patients with T2DM: an 18month prospective interventional study. Cardiovasc Diabetol. 2012;11(1):85.

32. Gagnon C, Lu ZX, Magliano DJ, Dunstan DW, Shaw JE, Zimmet PZ, et al. Low serum 25-hydroxyvitamin D is associated with increased risk of the development of the metabolic syndrome at five years: results from a national, populationbased prospective study (The Australian Diabetes, Obesity and Lifestyle Study: AusDiab). J Clin Endocrinol Metab. 2012 Jun;97(6):1953-61.

33. Pittas AG, Dawson-Hughes B, Li T, Van Dam RM, Willett WC, Manson JE, et al. Vitamin D and calcium intake in 
relation to type 2 diabetes in women. Diabetes Care. 2006 Mar;29(3):650-6.

34. Knekt P, Laaksonen M, Mattila C, Härkänen T, Marniemi J, Heliövaara M, et al. Serum vitamin D and subsequent occurrence of type 2 diabetes. Epidemiol Camb Mass. 2008 Sep.;19(5):666-71.

35. Liu S, Song Y, Ford ES, Manson JE, Buring JE, Ridker PM. Dietary calcium, vitamin D, and the prevalence of metabolic syndrome in middle-aged and older U.S. women. Diabetes Care. 2005 Dec;28(12):2926-32.

36. Pittas AG, Nelson J, Mitri J, Hillmann W, Garganta C, Nathan DM, et al. Plasma 25-hydroxyvitamin D and progression to diabetes in patients at risk for diabetes: an ancillary analysis in the Diabetes Prevention Program. Diabetes Care. 2012 Mar;35(3):565-73.

37. Pittas AG, Sun Q, Manson JE, Dawson-Hughes B, Hu FB. Plasma 25-hydroxyvitamin D concentration and risk of incident type 2 diabetes in women. Diabetes Care. 2010 Sep.;33(9):2021-3.

38. Grimnes G, Emaus N, Joakimsen RM, Figenschau Y, Jenssen T, Njølstad I, et al. Baseline serum 25hydroxyvitamin D concentrations in the Tromsø Study 1994-95 and risk of developing type 2 diabetes mellitus during 11 years of follow-up. Diabet Med J Br Diabet Assoc. 2010 Oct;27(10):1107-15.

39. Kostoglou-Athanassiou I, Athanassiou P, Gkountouvas A, Kaldrymides P. Vitamin D and glycemic control in diabetes mellitus type 2. Ther Adv Endocrinol Metab. 2013 Aug;4(4):122-8.

40. Chiu KC, Chu A, Go VLW, Saad MF. Hypovitaminosis D is associated with insulin resistance and beta cell dysfunction. Am J Clin Nutr. 2004 May;79(5):820-5.

41. Pittas AG, Lau J, Hu FB, Dawson-Hughes B. The role of vitamin $\mathrm{D}$ and calcium in type 2 diabetes. A systematic review and meta-analysis. J Clin Endocrinol Metab. 2007 Jun;92(6):2017-29.

42. Palomer X, González-Clemente JM, Blanco-Vaca F, Mauricio D. Role of vitamin D in the pathogenesis of type 2 diabetes mellitus. Diabetes Obes Metab. 2008 Mar;10(3):185-97.

43. Rammos G, Tseke P, Ziakka S. Vitamin D, the reninangiotensin system, and insulin resistance. Int Urol Nephrol. 2008 Jan. 10;40(2):419-26.

44. Tai K, Need AG, Horowitz M, Chapman IM. Vitamin D, glucose, insulin, and insulin sensitivity. Nutrition. $2008 \mathrm{Mar}$ 1;24(3):279-85.

45. Pinelli NR, Jaber LA, Brown MB, Herman WH. Serum 25-hydroxy vitamin $d$ and insulin resistance, metabolic syndrome, and glucose intolerance among Arab Americans. Diabetes Care. 2010 Jun;33(6):1373-5.

46. Oosterwerff MM, Eekhoff EMW, Heymans MW, Lips P, van Schoor NM. Serum 25-hydroxyvitamin D levels and the metabolic syndrome in older persons: a population-based study. Clin Endocrinol (Oxf). 2011 Nov;75(5):608-13.

47. Moy F-M, Bulgiba A. High prevalence of vitamin D insufficiency and its association with obesity and metabolic syndrome among Malay adults in Kuala Lumpur, Malaysia. BMC Public Health. 2011;11:735.

48. Cheng K-H, Huang S-P, Huang C-N, Lee Y-C, Chu C-S, Chang C-F, et al. The impact of estradiol and 1,25(OH)2D3 on metabolic syndrome in middle-aged Taiwanese males. PloS One. 2013;8(3):e60295.

49. Schauer PR, Kashyap SR, Wolski K, Brethauer SA, Kirwan JP, Pothier CE, et al. Bariatric surgery versus intensive medical therapy in obese patients with diabetes. $\mathrm{N}$ Engl $\mathrm{J}$ Med. 2012 Apr 26;366(17):1567-76.

50. Zhang Y, Zhao H, Cao Z, Sun X, Zhang C, Cai W, et al. A randomized clinical trial of laparoscopic Roux-en-Y gastric bypass and sleeve gastrectomy for the treatment of morbid obesity in China: a 5-year outcome. Obes Surg. 2014 Oct;24(10):1617-24.

51. Lee W-J, Chong K, Ser K-H, Lee Y-C, Chen S-C, Chen J$\mathrm{C}$, et al. Gastric bypass vs sleeve gastrectomy for type 2 diabetes mellitus: a randomized controlled trial. Arch Surg Chic Ill 1960. 2011 Feb.;146(2):143-8.

52. Schauer PR, Bhatt DL, Kirwan JP, Wolski K, Brethauer $\mathrm{SA}$, Navaneethan SD, et al. Bariatric surgery versus intensive medical therapy for diabetes-3-year outcomes. N Engl J Med. 2014 May 22;370(21):2002-13.

53. Wang MC, Guo XH, Zhang YW, Zhang YL, Zhang HH, Zhang YC. Laparoscopic Roux-en-Y gastric bypass versus sleeve gastrectomy for obese patients with type 2 diabetes: a meta-analysis of randomized controlled trials. Am Surg. 2015 Feb.;81(2):166-71.

54. Iannelli A, Anty R, Schneck AS, Tran A, Hébuterne X, Gugenheim J. Evolution of low-grade systemic inflammation, insulin resistance, anthropometrics, resting energy expenditure and metabolic syndrome after bariatric surgery: a comparative study between gastric bypass and sleeve gastrectomy. J Visc Surg. 2013 Sep.;150(4):269-75.

55. Buchwald H, Estok R, Fahrbach K, Banel D, Jensen MD, Pories WJ, et al. Weight and type 2 diabetes after bariatric surgery: systematic review and meta-analysis. Am J Med. 2009 Mar;122(3):248-56.e5.

56. Nannipieri M, Baldi S, Mari A, Colligiani D, Guarino D, Camastra S, et al. Roux-en-Y gastric bypass and sleeve gastrectomy: mechanisms of diabetes remission and role of gut hormones. J Clin Endocrinol Metab. 2013 Nov;98(11):4391-9.

57. Vidal J, Ibarzabal A, Romero F, Delgado S, Momblán D, Flores L, et al. Type 2 diabetes mellitus and the metabolic syndrome following sleeve gastrectomy in severely obese subjects. Obes Surg. 2008 Sep.;18(9):1077-82. 
58. Batsis JA, Romero-Corral A, Collazo-Clavell ML, Sarr MG, Somers VK, Lopez-Jimenez F. Effect of bariatric surgery on the metabolic syndrome: a population-based, long-term controlled study. Mayo Clin Proc. 2008 Aug;83(8):897-907. 59. Pories WJ, MacDonald KG, Morgan EJ, Sinha MK, Dohm GL, Swanson MS, et al. Surgical treatment of obesity and its effect on diabetes: 10-y follow-up. Am J Clin Nutr. 1992 Feb.;55(2 Suppl):582S - 585S.

60. Schauer PR, Burguera B, Ikramuddin S, Cottam D, Gourash W, Hamad G, et al. Effect of laparoscopic Roux-en Y gastric bypass on type 2 diabetes mellitus. Ann Surg. 2003 Oct;238(4):467-84; discussion 84-5. 